\author{
ACTA MYCOLOGICA \\ Vol. 48 (1): 105-112 \\ 2013
}

DOI: $10.5586 / \mathrm{am} .2013 .012$

\title{
Distribution of Erysiphe platani (Erysiphales) in Ukraine
}

\author{
VASYL P. HELUTA ${ }^{1}$, VIKTORIA G. KORYTNIANSKA ${ }^{2}$ and ILGAZ AKATA ${ }^{3}$
}

\author{
${ }^{1}$ M.G. Kholodny Institute of Botany of the National Academy of Sciences of Ukraine \\ 2 Tereschenkivska Str., UA-01601 Kyiv 01601, vheluta@botany.kiev.ua \\ ${ }^{2}$ National Research Restoration Centre of Ukraine, Odessa Branch, 7 Voznesensky Str. \\ UA-65058 Odessa, kutovaya@rambler.ru \\ ${ }^{3}$ Faculty of Science, Department of Biology, Ankara University, Tandogan \\ TR-06100, Ankara, akata@science.ankara.edu.tr
}

Heluta V.P., Korytnianska V.G., Akata I.: Distribution of Erysiphe platani (Erysiphales) in Ukraine. Acta Mycol. 48 (1): 105-112, 2013.

Information is provided on Erysiphe platani, a newly invasive fungus in Ukraine. The anamorph of this North American powdery mildew was first recorded in Ukraine in 1986 on Platanus orientalis in the Nikita Botanical Garden (Crimea). Later, it was found in other localities of the Crimean peninsula, and in Odessa and Odessa region on three species of plane, namely $P . \times$ hispanica, $P$. occidentalis and $P$. orientalis. Spread of the fungus was epiphytotic. This mildew significantly reduces the ornamental value of plane trees, which are often planted in public open spaces within urban areas of southern Ukraine. Recently, $E$. platani has formed the teleomorph in this region. Morphologically, the Ukrainian material is slightly different from the species description, viz. appendages are longer (up to 3 times the chasmothecial diam.), often with less compact apices.

Key words: powdery mildew fungi, Platanus, invasion, Europe, Odessa region, Crimea

\section{INTRODUCTION}

Recently, invasive species of powdery mildew originating from North America and East Asia have spread extensively in Ukraine and other European countries. In most cases, introduced trees and shrubs widely planted in the landscaping of city areas have been involved. Thus, such powdery mildews invading Ukraine during the first decade of this century include: Erysiphe azaleae (U. Braun) U. Braun et S. Takam. on rhododendrons (Rhododendron japonica (A. Gray) Suringar and R. luteum Sweet) (Heluta et al. 2004), E. flexuosa (Peck) U. Braun et S. Takam. on horsechestnut and five other species of the genus Aesculus L. (Heluta, Voytyuk 2004), E. elevata (Burrill) U. Braun et S. Takam. on catalpa (Heluta et al. 2009a), E. kenjiana (Homma) U. Braun et S. Takam. on several elm species (Heluta et al. 2009b), E. magnifica 


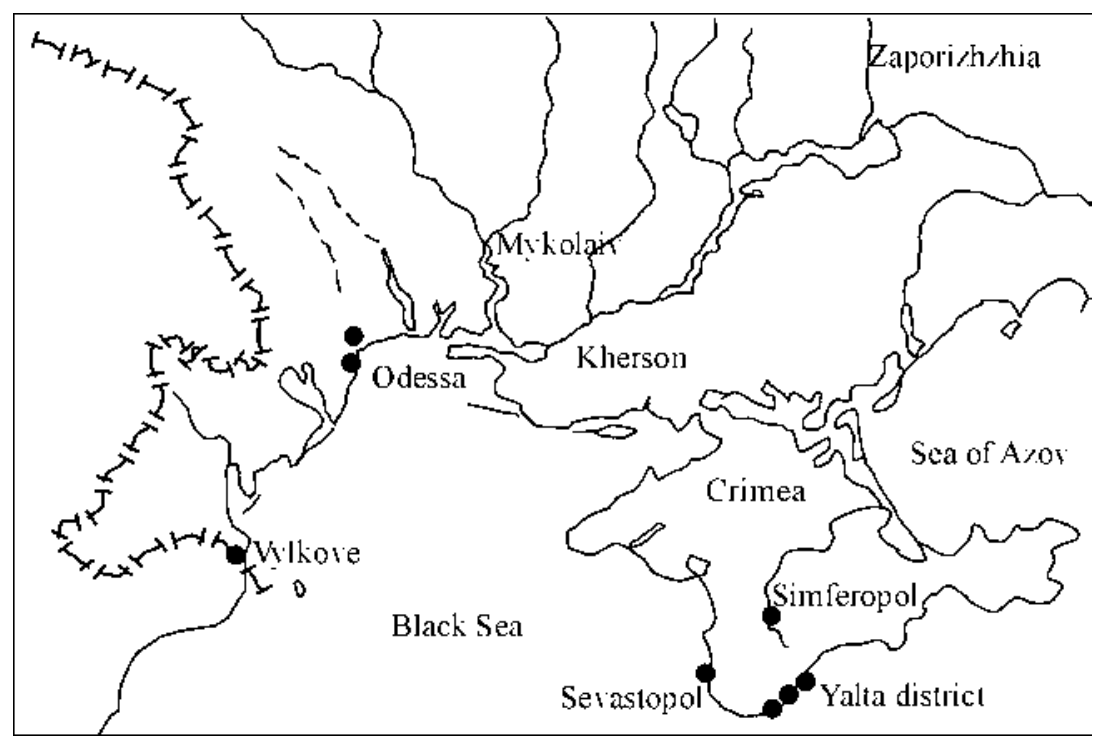

Fig.1. Distribution of Erysiphe platani in the southern part of Ukraine.

(Findings are represented by black dots).

(U. Braun) U. Braun et S. Takam. on 11 species of magnolia (Palagecha, Chumak 2011). The North American Erysiphe platani (Howe) U. Braun et S. Takam. parasitizing plane also falls into this category. In the early 1960's the fungus was introduced into Europe where it became widespread. Erysiphe platani (formerly Microsphaera platani) has been recorded in many countries, e.g. Bulgaria (Fakirova 1991), France (Viennot-Bourgin 1982; Kreisel, Scholler 1994), Germany (Kirschner 2011; Scholler et al. 2012), Greece (Vakalounakis, Klironomou 1995), Hungary (Pastirčáková, Pastirčák 2008), Italy (Bongarra 1981; Ialongo 1981), Portugal (Sequeira 1981), Romania (Negrean, Anastasiu 2006), Russia (Karpun 2012), Slovakia (Pastirčáková, Pastirčák 2006), Spain (Tello et al. 2000), Switzerland (Bolay 2005), the United Kingdom (Ing 1991; Jones, Baker 2007; observed also by V.P. Heluta in London in 2000), and Yugoslavia (Mijuskovic 1993). The fungus was also found in Asia. Now it is known in China (Liang et al. 2007), Georgia (Gvritishvili 2008), Israel (Halperin 1989; Voytyuk et al. 2008), Japan (Tanda 1999; Horie et al. 2002), and Turkey (Kavak 2007; Severoglu, Ozyigit 2012). Following the active introduction of its host, $E$. platani gradually spread to southern Africa (Gorter, Eicker 1985), South America (Luisi, San Martin 1987; Braun et al. 2000; Inokuti et al. 2008), Australia (Cunnington 2003), and New Zealand (Boesewinkel 1986).

Usually, alien species of powdery mildews entering Western Europe from North America, are soon recorded in Ukraine. Erysiphe platani was no exception. The fungus was first found by G. Ovcharenko in November 1986 on Platanus orientalis L. in the Nikita Botanical Garden in Crimea (Fig. 1). Collections were repeated the following year. Note that in both cases the fungus developed only the anamorphic state; therefore, it was later referred to a Pseudoidium sp. (Dudka et al. 2004). Obviously, some time later the mildew began to spread intensively in the south of Crimea, 
because in October and November 2005, samples (again only the anamorph) were collected on Platanus sp. by V.P. Heluta in Yalta, and L. Musatenko and L. Voitenko in Sevastopol. Still later, the fungus spread beyond the Crimea, and after 2010 it was repeatedly collected by V.G. Korytnianska in Odessa region. It infected at least two species of plane $(P . \times$ hispanica Mill. ex Muenchh. and $P$. occidentalis L.) and now formed fruiting bodies, allowing us to refer it to $E$. platani rather than merely to a Pseudoidium sp.

\section{MATERIALS AND METHODS}

Mycelium, conidiophores, conidia and chasmothecia were studied using dried herbarium specimens listed below. For light microscopy, mycelium, conidiophores and conidia were removed from the surface of infected leaves using transparent adhesive tape. To restore shape and size, a piece of tape with these fungus structures was put in a droplet of $40 \%$ lactic acid solution on a microscope slide, covered with a cover glass, gently heated to boiling point, then examined and photographed under a light microscope «Primo Star» (Carl Zeiss, Germany) using the Camera «Canon A 300» and software «AxioVision 4.7». Fruiting bodies were placed in a drop of distilled water. Digital data were treated statistically when $n$ was $\geq 30$ for each character.

The studied materials were deposited in the National Herbarium of M.G. Kholodny Institute of Botany of the National Academy of Sciences of Ukraine (KW).

\section{RESULTS AND DISCUSSION}

All specimens of powdery mildew collected on Platanus L. in Crimea and Odessa region of Ukraine were found to belong to E. platani, and generally corresponded to the description of this species, but their chasmothecial appendages are much longer (up to three times the chasmothecial diameter) than stated in the monograph by Braun and Cook (2012). Moreover, in some cases, our material was slightly distinguished by the elongation of some branches of the first or second order, so that apical parts of appendages could hardly be considered compact. In addition, one specimen of the fungus from Turkey (only anamorph) was identified making it the third record of E. platani in that country. Its morphology matched that of the Ukrainian material.

There follows a description, distribution, location, date of collection and micrographs of the species, and a brief discussion of the materials studied.

Erysiphe platani (Howe) U. Braun et S. Takam., Schlechtendalia 4: 12 (2000).

Bas. Microsphaera platani Howe, in Bessey, Bull. Torrey Bot. Club 5: 4 (1874).

Syn. Microsphaera penicillata f. platani Jacz., Karm. Opred. Grib., Vip. 2. Muchn.-rosj. griby (Leningrad): 359 (1927).

Mycelium mostly epiphyllous forming more or less pure white spots or amphigenous dirty-yellowish, irregular and diffuse patches (Fig. 2A). Anamorph of Pseudoidium type. Conidia very variable in shape and size, mainly elongated-ellipsoidal to 

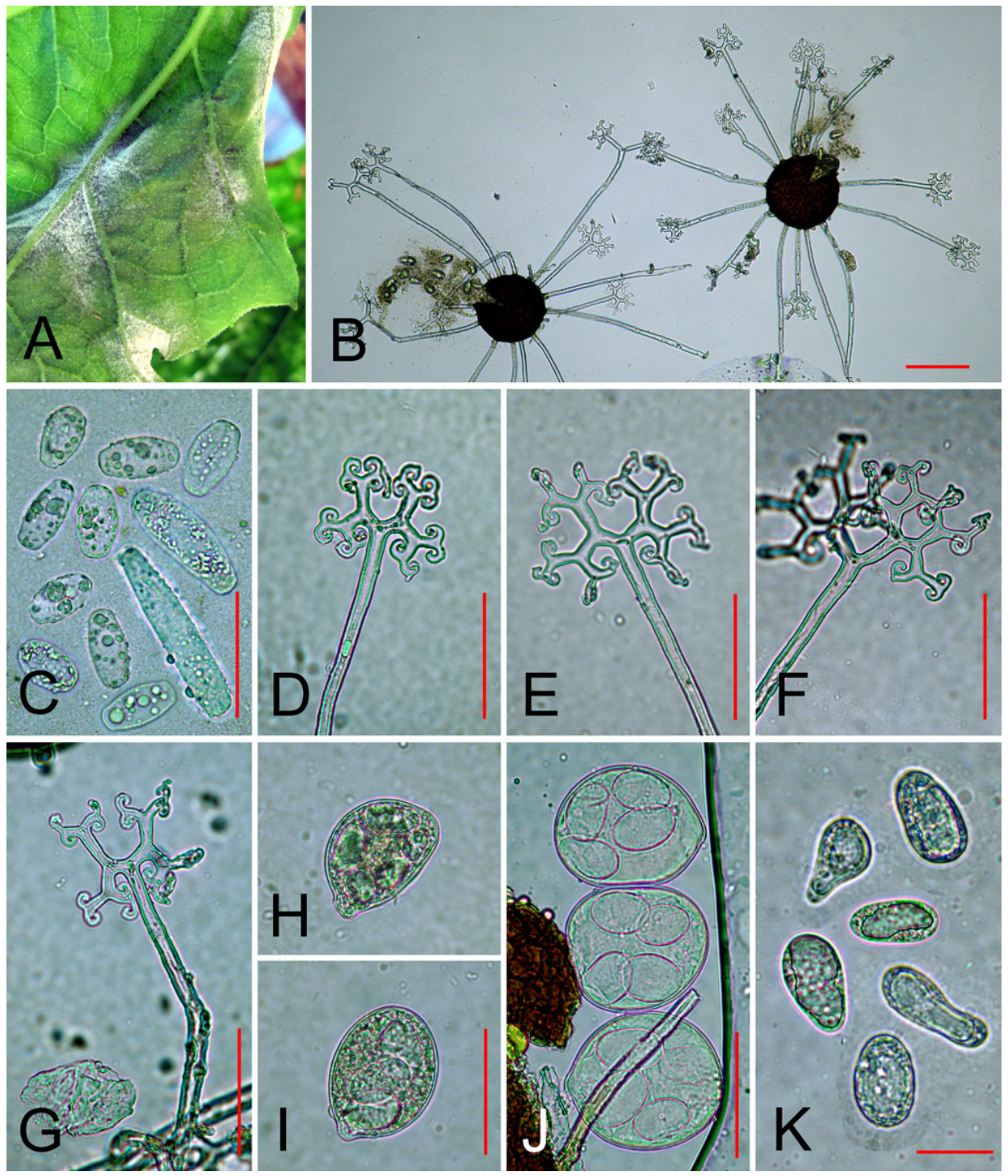

Fig. 2. Erysiphe platani on Platanus spp.: A - the part of the host plant leaf (lower surface) affected by the fungus; B - chasmothecia with appendages; $\mathrm{C}$ - conidia; D-G - apical parts of the appendages $(\mathrm{D}$ - compact, $\mathrm{E}$ - intermediate, $\mathrm{F}$ - relatively loose with elongated primary branches, and $\mathrm{G}$ - relatively loose with elongated secondary branches); H-J - asci ( $\mathrm{H}$ - cover slip not pressed down, I - pressed slightly, and $\mathrm{J}$ - pressed hard); $\mathrm{K}$ - ascospores. Scale bars: $\mathrm{B}=100 \mu \mathrm{m}, \mathrm{C}-\mathrm{J}=50 \mu \mathrm{m}$, and $\mathrm{K}=20 \mu \mathrm{m}$.

ellipsoidal, often slightly vase-shaped, sometimes very elongated, to almost cylindrical with rounded ends, 32.5-37.0(-40.0) × 15.0-17.5(-20.0) $\mu \mathrm{m}$ (Fig. 2C). Chasmothecia numerous, scattered, sometimes only in groups on the underside of the leaf in places beneath patches of mycelium that formed on the upper side of the leaf, dark brown, hemispherical, impressed in the lower part, 85-125 $\mu \mathrm{m}$ diam. (Fig. 2B). 
Appendages mostly 6-14, rarely more, up to 24 , equatorial, straight or slightly arcuate, simple, not septate or sometimes with a septum near the base, colourless, occasionally pale brown at the base, up to $350 \mu \mathrm{m}$ long, apices (3-)4-5(-6) times dichotomously branched, compact (Fig. 2D), but primary branches often elongated by up to 30, sometimes even $55 \mu \mathrm{m}$ (Fig. 2F), or secondary branches somewhat less elongated (by up to $20 \mu \mathrm{m}$, Fig. 2G), tips distinctly recurved when mature. Asci 6-8, ellipsoid or nearly spherical, slightly unequally sided (Fig. $2 \mathrm{H}$ ), mostly short-stalked, occasionally sessile, thin-walled, (42.5-)50.0-67.5 × 32.5-47.5 um, 3-4(-6)-spored (Figs 2I-2J). Ascospores mainly ellipsoid, oblong-ovate, rather large, 20.0-27.5 × 12.5-17.5 $\mu \mathrm{m}$ (Fig. 2K).

Distribution in Ukraine (Fig. 1).

On Platanus $\times$ hispanica Mill. ex Muenchh.: Autonomous Republic of Crimea: Simferopol, Karl Liebknecht St., 22.10.2012, leg. G. Danyliuk (anamorph); Yalta district, Alupka, Vorontsov Palace courtyard, 26.10.2012, leg. G. Danyliuk (anamorph). Odessa: Malinovsky district, A.M. Gorky Park of Culture and Rest, 18.09.2010 (KW 40027F), 01.08.2011; Primorsky district, Admiralsky Ave., 30.09.2012; Yekaterinynska St., 08.10.2012; Pasteur St., 16.11.2012; Peremohy arboretum, 21.08.2011 (KW 40028F), 26.08.2011, 21.10.2011; Pryvokzalna Square, 10.11.2011; Suvorov district, 10th Line St., 26.09.2012; 89 Dobrovolsky Ave., 06.10.2012; Zabolotny St., 12.09.2011, 04.10.2012; Marselska St., Kindergarten 42, 05.10.2012; Orlovska St., School 48, 04.10.2012; Paustovsky St., 06.11.2011. Odessa region: Kiliya district, Vylkove, Lenin St., 11.11.2012; Tatarbunar Povstannia St., 11.11.2012.

On P. occidentalis L.: Odessa: Malinovsky district, Cosmonauts St., 12.11.2011; Primorsky district, Velyka Arnautska St., 10.11.2011; Dyukivsky Garden Park, 12.11.2011; City Garden Park, 08.10.2012; square near the Opera House, specimen trees of local importance (150, 165 and 175 years old), 08.10.2012; Palais Royal Square, locally important specimen trees (127 and 132 years old), 08.10.2012; Panteleimonivska St., 29.09.2011 (KW 40031F); Preobrazhenska St., 25.10.2011; 1 Prymorsky Blvd., Pushkin's Plane, locally important specimen tree (170-175 years old), 08.10.2012; Pushkin St., 10.11.2011; Rozumovsky St., 27.10.2012; Tchaikovsky Lane, 08.10.2012; Champagne Lane, Square near the biological faculty of the I.I. Mechnikov Odessa National University, 09.11.2012; Suvorov district, Captain Kuznetsov St., near the Silpo supermarket, 05.10.2012. Odessa region: Bilyaivsky district, near Usatove village, park of Hadzhibey children's sanatorium, 14.08.2011, 16.10.2011 (anamorph).

On $\boldsymbol{P}$. orientalis L.: Autonomous Republic of Crimea, Yalta district, Nikita, Nikita Botanical Gardens, 20.11.1986, leg. G. Ovcharenko (anamorph; KW 31550F); ibid, in 1987, leg. G. Ovcharenko (anamorph, KW 31551F).

On Platanus sp.: Autonomous Republic of Crimea: Sevastopol, near the Institute of Biology of Southern Seas, park, 01.10.2005, leg. L. Musatenko and L. Voitenko (anamorph); Sevastopol, Uchkuyivka, 01.10.2005, leg. L. Musatenko and L. Voitenko (anamorph); Yalta, near the seafront, 11.11.2005, leg. V. Heluta (anamorph); Pushkinska St., 21.08.2007, leg. V. Heluta (KW 40029F). Odessa: Primorsky district, Rishelievska St., 28.09.2011 (KW 40030F); ibid, near the intersection with the Arnautska St., 19.10.2011; Suvorov district, Kurska St., 11.10.2011. 
NotE: All specimens from Odessa and Odessa region were collected by V. Korytnianska, so the name of the collector is not specified.

As already mentioned, the specimen of E. platani on Platanus sp. collected in Turkey, Antalya, Alanya, Konakli, in September 2011, leg. O. Peregrym (KW 40032F), was included in the study.

It should be noted that due to their high ornamental value, unpretentiousness and tolerance to adverse environmental conditions, plane-trees are widely used in landscaping of the southern cities of Ukraine. In Odessa they are represented by the three species, $P$. $\times$ hispanica, $P$. occidentalis and $P$. orientalis, but only the first two are widely cultivated in the city (Kovalenko, Bonetsky 1985). Stately planetrees are a hallmark of the city and decorate the famous streets and boulevards, e.g. Rishelievska and Pushkinska Streets or Primorsky Boulevard. The oldest of them were given the special conservation status of 'botanichna pamiatka pryrody mistsevoho znachennia' (Popova et al. 2006). Unfortunately, powdery mildew caused by $E$. platani is very harmful to both old and young trees. A naturally dense down on young leaves that usually disappears as healthy leaves mature remains on damaged parts of the leaf. As a result of the disease, leaves are covered with a more or less thick white or grey coating of plant hairs combined with mycelium, conidiophores and conidia of the fungus. This often results in holes and cracks causing significant deformation of the lamina and young infected shoots often wither. Thus, trees lose appreciable ornamental value and become a source of additional air pollution due to the release of large numbers of conidia. The disease is already epiphytotic in Odessa and Odessa region.

Acknowledgements. Authors are grateful to Mrs. G. Danyliuk, Dr. L. Musatenko, Dr. G. Ovcharenko, Dr. O. Peregrym, and Dr. L. Voitenko for kindly providing of specimens of plane leaves infected with powdery mildew. We also thank Dr. Roger Cook for help with the English and valuable comments on the manuscript.

\section{REFERENCES}

Boesewinkel H.J. 1986. New plant disease records from New Zealand. Australas. Plant Pathol. 15 (1): $18-21$.

Bolay A. 2005. Les Oïdiums de Suisse (Erysiphacées). Cryptog. Helv. 20: 1-176.

Bongarra C.S. 1981. Gravi attachi di «oidio» su platano orientale in Sicilia. Inform. Fitopatol. 31 (4): 13-15.

Braun U., Cook R.T.A. 2012. Taxonomic manual of the Erysiphales (powdery mildews). CBS Biodiversity Series 11: 1-707.

Braun U., Kiehr M., Delhey R. 2000. Some new records of powdery mildew fungi from Argentina. Sydowia 53 (1): 34-43.

Cunnington J. 2003. Pathogenic fungi on introduced plants in Victoria. A host list and literature guide for their identification. Department of Primary Industries, Knoxfield.

Dudka I.O., Heluta V.P., Tykhonenko Yu.Ya., Andrianova T.V., Hayova V.P., Prydiuk M.P., Dzhagan V.V., Isikov V.P. 2004. Hryby pryrodnykh zon Krymu. Phytosociocentre, Kyiv.

Fakirova V.I. 1991. Gebite v Blgaria. Tom 1. Razred Erysiphales. Izdatelstvo na Blgarskata akademia na naukite, Sofia.

Gorter G.J.M.A., Eicker A. 1985. New South African records of Erysiphaceae from the Transvaal II. S. Afr. J. Bot. 51: 339-343. 
Gvritishvili M.N. 2008. On fungal diseases of cultivated and wild woody plants new to Georgia. Abstract of 1st International Transcaucasus conference on plant pathology, Tbilisi.

Halperin I. 1989. Three diseases and pests of plane trees in Europe and the threat they pose in Israel. Hassadeh 69: 1111-1112.

Heluta V.P., Dzyunenko O.O., Cook R.T.A., Isikov V.P. 2009a. New records of Erysiphe species on Catalpa bignonioides in Ukraine. Ukr. Bot. Zhurn. 66 (3): 346-353.

Heluta V., Takamatsu S., Voytyuk S., Shiroya Y. 2009b. Erysiphe kenjiana (Erysiphales), a new invasive fungus in Europe. Mycol. Prog. 8 (4): 367-375. http://dx.doi.org/10.1007\%2Fs11557-009-0610-8

Heluta V.P., Voytyuk S.O. 2004. Uncinula flexuosa Peck - novyi dlia Ukrainy vyd invazijnoho boroshnystorosianoho hryba (Erysiphales). Ukr. Bot. Zhurn. 61 (5): 17-25.

Heluta V.P., Voytyuk S.O., Chumak P.Ya. 2004. Microsphaera azaleae U. Braun - novyi dlia Ukrainy vyd boroshnystorosianoho hryba (Erysiphales). Ukr. Bot. Zhurn. 61 (2): 27-33.

Horie H., Sato Y., Takeuchi J. 2002. First occurrence of powdery mildew on Platanus in Tokyo, Japan. Annu. Rep. Kanto-Tosan Plant Prot. Soc. 49: 65-68.

Ialongo M.T. 1981. Indizi di specializzazione in un "Mal bianco" del platano comune (Platanus hybrida Brot.). Ann. Ist. Sper. Pat. Veg., Roma 7: 103-114.

Ing B. 1991. An introduction to British powdery mildews. 7. The Mycologist 5 (3): 156-157. http://dx.doi. org/10.1016\%2FS0269-915X\%2809\%2980319-4

Inokuti E.M., Soares D.J., Barreto R.W. 2008. Discovery of Erysiphe platani anamorph on Platanus $\times$ hispanica from Brazil. Plant Pathol. 57 (2): 375.

Jones D.R., Baker R.H.A. 2007. Introductions of non-native plant pathogens into Great Britain, 19702004. Plant Pathol. 56 (5): 891-910.

Karpun N.N. (2012 onwards). Representatives of Erysiphaceae family on flower-and-ornamental varieties in Sochi. http://www.rusnauka.com/9_NND_2012/Biologia/3_105889.doc.htm

Kavak H. 2007. Erysiphe platani, an anamorphic powdery mildew on Platanus orientalis in Turkey. Plant Pathol. 89 (2): 303.

Kirschner R. 2011. Observations on Erysiphe platani in Germany. Plant Pathol. Quar. 1 (2): 115-119.

Kovalenko S.G., Bonetsky A.S. 1985. Parki nad morem: Krayevedcheskiy ocherk. Mayak, Odessa.

Kreisel H., Scholler M. 1994. Chronology of phytoparasitic fungi introduced to Germany and adjacent countries. Bot. Acta 107 (6): 369-472.

Liang C., Lu G.Z., Shin H.D. 2007. First report of powdery mildew of Platanus orientalis caused by Erysiphe platani in China. New Disease Reports 15: 11.

Luisi N., San Martin J. 1987. Mal blanco del genero Platanus en Chile. Bosque 8 (1): 7-11.

Mijuskovic M. 1993. Powdery mildew of plane tree, a new disease for Yugoslavia. Poljoprivreda i sumarstvo 39 (1/2): 31-34.

Negrean G., Anastasiu P. 2006. Invasive and potentially invasive parasite neomycetes from Romania. Plant, fungal and habitat diversity investigation and conservation. Proceedings of IV BBS, Sofia.

Palagecha R.M., Chumak P.Ya. 2011. Ekoloho-morfolohichna struktura subpopulatsii Microsphaera magnifica U. Braun (Erysiphales) ta invazijna spromozhnist tsioho hryba. Materialy XIII zjizdu Ukrainskoho botanichnoho tovarystva. Lviv, TzOV «Prostir M».

Pastirčáková K., Pastirčák M. 2006. The anamorph of Erysiphe platani on Platanus $\times$ hispanica in Slovakia. Mycotaxon 97: 189-194.

Pastirčáková K., Pastirčák M. 2008. Erysiphe platani causing powdery mildew of London plane in Hungary. Acta Phytopathol. Entomol. Hung. 43 (1): 31-36.

Popova O.M., Uzhevska S.Ph., Yurchenko Yu. 2006. Reyestr pryrodno-zapovidnoho fondu Odeskoi oblasti. FOP Fedyaev, Odessa.

Scholler M., Hemm V., Lutz M. 2012. Erysiphe platani: monitoring of an epidemic spread in Germany and molecular characterization based on rDNA sequence data. Andrias 19: 263-272.

Sequiera de M.P. da Silva. 1981. O Oídio-do-plátano em Portugal. Agron. Lusi. 40 (3): 299-301.

Severoglu Z., Ozyigit I.I. 2012. Powdery mildew disease in some natural and exotic plants of Istanbul, Turkey. Pak. J. Bot. 44: 387-393.

Tanda S. 1999. Powdery mildews on some ornamental trees and their causal fungi from Japan. J. Agr. Sci. 43: 253-259.

Tello M.L., Redondo C., Mateo-Sagasta E. 2000. Health status of plane trees (Platanus spp.) in Spain. J. Arboric. 26 (5): 246-254. 
Vakalounakis D.J., Klironomou E. 1995. Severe attack of Microsphaera platani on Platanus orientalis var. cretica in Crete (Greece). EPPO Bull. 25: 463-466.

Viennot-Bourgin G. 1982. Trois oïdiums nouveaux pour la France. Phytoma, Déf. Cult. 336: 34.

Voytyuk S.O., Heluta V.P., Wasser S.P., Nevo E., Takamatsu S. 2009. Biodiversity of the Powdery Mildew Fungi (Erysiphales, Ascomycota) of Israel (Biodiversity of Cyanoprocaryotes, Algae and Fungi of Israel). A.R.G. Gartner Verlag, Ruggell. 